\title{
The Effect of Creative Movement-Dance on the Development of Basic Motor Skills of Pre-School Children
}

\author{
Eleni Tsompanaki \\ Correspondence: Eleni Tsompanaki, School of Humanities and Social Sciences, Department of Early Childhood \\ Education, University of Thessaly, Volos, Greece.
}

Received: March 6, 2019 Accepted: April 2, 2019 Online Published: April 10, 2019

doi:10.5539/res.v11n2p29 URL: https://doi.org/10.5539/res.v11n2p29

\begin{abstract}
The purpose of this study is to evaluate the effectiveness of a program for children aged 4-5 with the main tool of creative movement - dance and its influence on the development of basic motor skills. The aim of the intervention program is to develop "moving" motor skills through an organized intervention program with a variety of creative moves and creative dance. The intervention program aims to create a positive environment in which children can overcome negative emotions and join the team, communicate, experiment, discover, co-decide and create new kinetic dance forms.
\end{abstract}

Keywords: movement-dance, motor skills, pre-school children

\section{Introduction}

The first form of communication is not verbal but kinetic. From the very first days of our life, we communicate through a series of rhythmic movements. The movements are the first form of communication, the body speaks through movement around until the age of two. We use our body to express, to learn, to understand, to create.

The most important representatives of the theory of movement and creativity were Guilford, Taylor, Maslow, Storr, Torrance, Laban and more. They have set the base for further research to develop. Kinetic/movement creativity is the ability of a child to express his/her own ideas, to change and perfect another, to mimic and represent situations he/she has experienced and to create new forms according to his/her experiences. In that way, a child reaches understanding of meanings.

Kinetic creativity is a privilege for all children (high and non-intelligence) and is a source of energy release. This is enhanced when given the appropriate stimuli and motivation to experiment, discover and create with their active engagement. Past experiences enable the child to think, analyze things, situations, and build on new experiences based on past experiences (Storr, 1991; Xanthakou, 1998; Pica, 2004; Mulvey et all 2018; Mpourneli, 2006; Tsapakidou, 2014). Every child is born with creative potential which he/she must cultivate as it is crucial for his/her development (Gardner, 1993).

Creative movement is not based on rules and there are no wrong choices. Children get a stimulus and react physically according to their personal and unique way. This is achieved through improvisation.

\subsection{The Art of Dance in Education}

The art of dance in education lies in the need to allow participants to understand and explore themselves. Dance is a vehicle for communication, expression and acceptance. It is generally believed that dance assists the intrinsic values of dance when applied in education. Thus, it opens up possibilities for self-awareness and development. The aim of dance is to develop a child socially, psychologically, mentally, emotionally, cognitively and this occurs through physical engagement (Brinson, 1991; McFee, 1985). It is important to understand that the intrinsic elements of dance are what matters in education. Several researches have focused on the pedagogical benefits of dance in education (Benn, 2003; Best, 2004; Tsompanaki, 2009; Becker, 2013). Some of them concern aesthetic education, creativity, critical thinking, empathy, metacognition (Smith-Autard, 2002; McFee, 2004; Best, 2004; Redfern, 2007; Tsompanaki, 2009; Spanaki et all., 2010).

Dance in education promotes artistic, cultural, social, multicultural and multidisciplinary education. The child will develop in that way self-knowledge, self-respect, autonomy, connection between feelings, thoughts and actions. He /she will be able to control his/her feelings and thoughts, develop his/her communicative skills, develop trust with others and will develop his/ her collaborative skills. 
Teacher should approach dance holistically in order to allow these elements to flourish. Dance can enrich teachers' curriculum and tutorial, allowing them to give inquiry in the learning process (Kambas,et all 2012, 2010; Kockenberger, 2004).

This perception must seek for the pleasure of knowing, it must exploit the child's natural curiosity, give an incentive for learning, must seek to improve child's ability to communicate at all levels and encourage co-operation (Pavlidou et all, 2018; Zarić et all, 2018). Teachers work multifarious, avoids stereotypes in learning processes and teacher-centered education. This approach allows theory to connect with practice, enriches research and makes the subject matter a game.

Movement and play is an irreplaceable part of children's life. Introducing play in class is bringing knowledge closer to child's reality (Montessori, 1936). This unique, original and multi-significant way of expression of every art form, enriches the allure of this communication.

\subsection{Creative Dance and Education}

The innovative work of Rudolph Laban created a new language that allowed a subjective conversation on the movement analysis to develop. His contribution in the areas of movement observation, decoding, analysis and its application to every human effort has set the theoretical and practical foundations of his method. The term creative dance was created by him and was applied mostly in education. He focused not on how we move, but what moves us (Laban, 1986). Therefore, when we talk about dance in education, we refer to creative dance.

Based on the development of the philosophy of education, contemporary educators and teachers should challenge themselves in order to improve their teaching approaches. They should allow children create something new according to their personality, fantasy and creativity and not just to require them to copy their teacher. This is one of the fundamental elements of creative dance. Creative dance utilizes simple, every day movement, giving emphasis on the kinetic particularity and not on the kinetic ability. Physical abilities and skills are mostly connected with specific dance genres and dance in education tends to be either a creative form of movement that emphasises only on creativity and mental development or a specific dance style (ballet, contemporary, traditional, jazz, etc) that gives emphasis on the development of physical skills. The question is whether kinetic ability and skills can be achieved through a creative dance class?

In a creative dance class, improvisation is a fundamental element of the structure of the class. Improvisation allows participants connect knowledge with pleasure, through a very personal movement experience. Improvisation, which requires the creation of new motor ideas, is the catalytic activity in the teaching process at each stage of dance learning. Improvisation is an important aid to the development of creative and critical ability. Through improvisation and composition, the ability to explore is developed. In that way, children engage in exploration; exploration of the body, of the space, their interaction with others, the qualities and the dynamics of movement (Laban, 1975).

Pre-school education is a crucial period where the child develops character and fundamental cognitive elements. Creative dance allows this to flourish through the use of movement. Thus, it is the movement skills and abilities that enrich artistic, aesthetic, social, cognitive, emotional education and so on. Creative dance is also an evolute of movement skills and it is through the development of movement skills and abilities that children grow in multiple ways. There should not be a dualism. Pre-school age is considered as an appropriate period for the implementation of programs that aim at promoting motor skills. It is the age at which the foundations for children's fundamental skills are built, which will later develop also into sports skills (Gallahue, 2002).

Therefore, it is logical that guidelines in pre-primary education should include the development and promotion of motor skills and should play an integral part of educational programs (Vidoni et all, 2014). The NASPE (NASPE, 2009), highlights the importance of organized movement programmes, at least one hour per day (Pavlidou et all, 2018), especially for children of that age who need to be active and not fixed. This justifies the increasing obesity, for example (Dyment and Coleman, 2012; Mülazımoğlu-Ball, 2016; Zarić et all, 2018).

Research has shown that children do not exercise adequately and are not involved in physical activities like dancing or playing active games (Tucker, 2008). Researches that have been conducted in kindergarten schools, show that the presence of motor activities in Greece and abroad is unsatisfactory (Hinkley et all, 2008; Kambas et al, 2012; Kambas et al, 2015; Pavlidou et all, 2018; Yilmaz et all, 2018).

Interventional programs for motor activities, play and dance showed how effective they are in developing basic motor skills and thus, cognitive development in kindergarten and primary school children (Madic et all, 2018; Becker, 2013; Yilmaz et all, 2018; Zachopoulou et all, 2004; Shoval et all, 2015; Venetsanou \& Kambas, 2009; Wang, 2004; Goodway et all, 2003).

Therefore, the aim of this research is to evaluate the effectiveness of a program, for children 4 to 5 years old, having creative movement and dance and its influence on the development of basic motor skills, as its main tool. The aim of the intervention program is to develop "moving" motor skills through creative movement and dance. The intervention 
program aims to create a positive environment in which children can overcome negative emotions and join the team, communicate, experiment, discover, co-decide and create new kinetic dance forms.

\subsection{Investigation Case}

Stabilization skills, handlings along with movement skills do not develop automatically. The transition from the initial stage to a mature one is progressive and is mainly due to environmental factors. These include opportunities for practice, encouragement and teaching.

Based on the fundamental motor skills, this study was carried out - study with intervention programs of creative movement and dance in preschool children. Basic skills of movement include running, jump, consecutive jumps and hopping. The various forms of movement have an evolutionary path from walking to jogging and from jumping to one foot, to both feet, to the horizontal jump. They are basic skills of the human body that form the basis for every sporting-dance activity (Gallahue, 2002).

\subsection{Questions of the Study}

a) What is the effectiveness of an intervention program in motor skills on four to five year old children attending a nursery?

b) What are the differences in the comparison of the experimental and control group's kinetic skills in specific variables such as running, galloping, hopping, stride jumping, horizontal jump and leaping?

c) What is the effect of gender on the motor skills of children?

(d) Can movement skills and abilities be developed through an intervention programme that is based on creative dance?

The assumptions of the study are delineated on specific axes, aiming at the development of basic motor skills, and in particular the experimental team was called upon to exercise a) gross movements b) teamwork with collaboration c) experimentation with different materials d) rhythms, sounds and musical forms e) communication with the educator and the group.

\subsection{Originality}

The originality of this study is the Structure of the content of the intervention program with creative dance music-kinetic activities,

\section{Method}

\subsection{Sample}

The study involves two infant groups from a nursery. One group with 20 children is the experimental group and the other group constitutes the control group. More specifically, 40 children, of whom 18 were boys and 22 girls, aged 3.5-5 years, participated in the study.

20 children constitute the experimental group, who participated in the intervention program and the other 20 constitute the control group, where the nursery school teacher was running her own programs.

The place where the intervention took place was common to both groups. The researcher performed the

1 group. Intervention in the experimental group lasted two months with a specific program. A prerequisite for selecting the sample was that children should not participate in out-of-school sports such as creative dance, ballet, drama and other athletic activities.

\subsection{Research Tool}

For the evaluation of the children's coarse motor skills, the Ulrich Tummy Growth Test (TGMD-2, 2002) designed for children aged 3 to 10 years.

Prior to initiation of the intervention, both groups were evaluated in the Urlich test (TGMD-2, 2002), (pre and post test). Finally, the same test (post test) was performed in both groups.

The test can be divided into two sub-tests, the mobility skills sub-test and the sub-test skills .The mobility sub-test includes six skills that are tested on each child, with specific criteria. The exercises are: Running, galloping, laughing, stride jumping, horizontal jump, jogging-sliding. Each test is performed twice by each child and scored and both attempts are calculated.

Ulrich according to the results gives the kinetic development level the following characteristics:

- Very High, High, Above Average, Average, Under Average, Poor, Very Poor

- The confidence factor between different measurements was 0.96 for motor skills and 0.97 for handling skills. 


\subsection{Content and Structure of the Intervention Program}

The research process was based on two axes: a) body and space knowledge, b) dynamics of movement and relationships.

As for the first axis of body knowledge, movements of body parts (support, strength, agility) and body shapes (straight, round, curved shapes) were included. Knowledge of space included the ability to recognize and use the personal and general space, the levels (high, medium, low), directions (up, down, forward, backwards) various materials and gymnastics at individual and team level. The first 8 lessons referred to the above objective with essentially creative content enriched with music, and dance. The children learned to use their body, express themselves through it, discover new movements as to what they can do, and discover their own space. The main goal was to teach children to know their body and the movements assisted from different body parts, in relation to the space (general and personal). Furthermore, they learnt to move using different directions, levels, positions, paths and shapes. They also learned to recognize the right and left sides and react with kinetics to various stimuli, acoustic and visual stimuli.

The predominant element was children's perception, readiness and responsiveness to the stimuli that the program put through the educator.

In terms of the second axis, the programs were based on the dynamics of movement and the relationships created by the game itself. The next steps were more demanding and contained creative dance accompanied by music, expressive movements, improvisation. The activities and games of the program had as their main objective the acquaintance of the body, the perception of space and rhythm, balance, coordination, readiness, teamwork and cooperation, and finally, improvisation with the enhancement of creativity. Generally, stimulus was given so that the infant would create new original movements. At the same time, through stories, fairy tales, pictures, situations, kinetic ideas or attitudes and forms of the body were given so that children would have the opportunity to decode them, explore them using qualities and dynamics of movement and thus, understand them. The content of the programs consisted of dances from all over the world, such as Greek, Mexican, American, Tarantula and Russian, all through a creative approach such as improvisation and games.

\section{Results}

In the present study, the performance of an interventional learning process in motor skills was studied. The study was conducted in children aged 4-5 years, divided into two groups of 20 individuals each, the control group and the intervention team (experimental). In both groups, two measurements were made at two different time points, including interventional teaching only on experimental. The Kinetic Skill Measurement Tool was the Urlich's test.

In Table 1 and Figure 1, we see the gender of the children who participated in the two research groups. In the experimental group, $40 \%$ were boys and $60 \%$ girls, while in the control group the percentages were divided by half between the two sexes (50\% boys, $50 \%$ girls).

Table 1. Gender

\begin{tabular}{|c|c|c|c|c|}
\hline & & & Frequency & Valid Percent \\
\hline \multirow{3}{*}{ Experimental } & \multirow{3}{*}{ Valid } & Boy & 8 & 40.0 \\
\hline & & Girl & 12 & 60.0 \\
\hline & & Total & 20 & 100.0 \\
\hline \multirow{3}{*}{ Control } & \multirow{3}{*}{ Valid } & Boy & 10 & 50.0 \\
\hline & & Girl & 10 & 50.0 \\
\hline & & Total & 20 & 100.0 \\
\hline
\end{tabular}




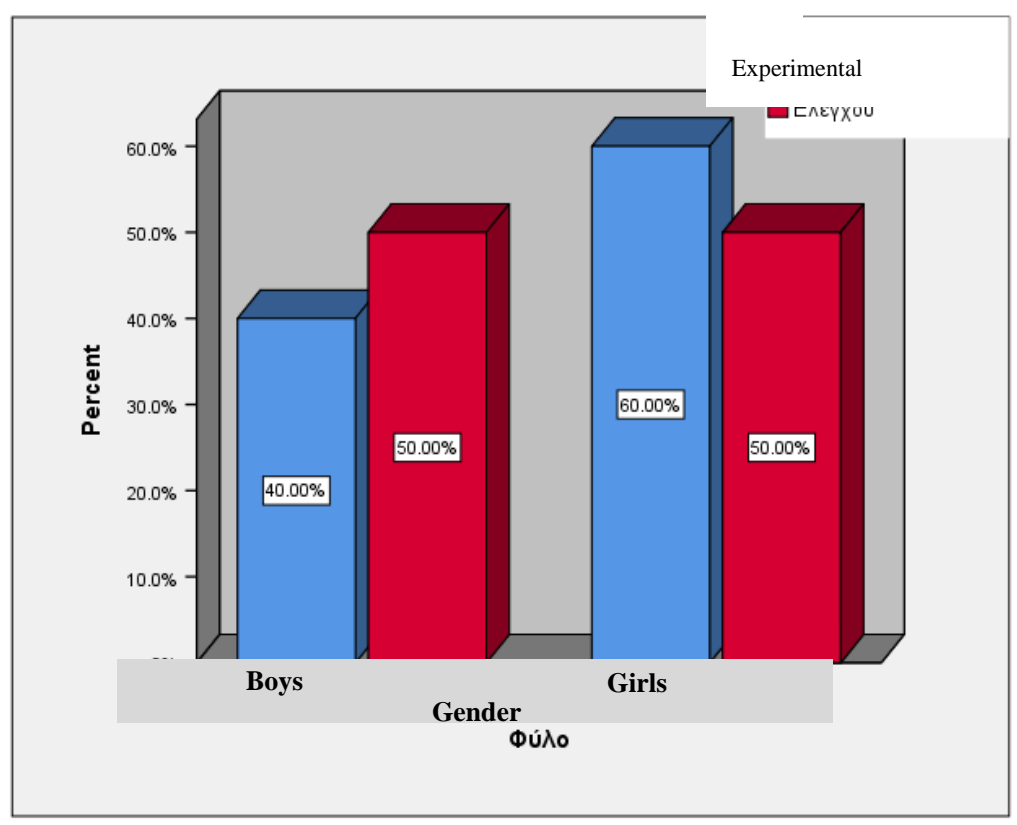

Figure 1. Gender

In Table 2, we see the mean values of the children's scores for both measurements in the two study groups. Obviously, the average scores in the experimental group have a clear difference, since before the intervention the average Score was 6.90, then it was 10.65.In the control group, these differences are very small, as in the first measurement we had an average of 7.05, while in the second measurement 7.45

Table 2. Mean values and standard deviations of scores in the two groups

\begin{tabular}{|c|c|c|c|c|}
\hline Group & & & $\begin{array}{l}\text { Performance } \\
\text { before }\end{array}$ & $\begin{array}{l}\text { Performance after } \\
\text { intervention }\end{array}$ \\
\hline \multirow{4}{*}{ Experimental } & \multirow{2}{*}{$\mathrm{N}$} & Valid & 20 & 20 \\
\hline & & Missing & 0 & 0 \\
\hline & \multicolumn{2}{|c|}{ Mean } & 6.90 & 10.65 \\
\hline & \multicolumn{2}{|c|}{ Std. Deviation } & 1.410 & 1.225 \\
\hline \multirow{4}{*}{ Control } & \multirow{2}{*}{$\mathrm{N}$} & Valid & 20 & 20 \\
\hline & & Missing & 0 & 0 \\
\hline & \multicolumn{2}{|c|}{ Mean } & 7.05 & 7.45 \\
\hline & \multicolumn{2}{|c|}{ Std. Deviation } & 1.468 & 1.394 \\
\hline
\end{tabular}

Below, in Graphs 2 and 3, we see the rankings of the same people in "before" and "after". The horizontal axis has the number of children who participated in the survey, while the vertical has the corresponding scores for each. In this way, differences in the experimental group are now very clear, since after the intervention all the children performed better (the orange line is entirely above the blue) and for the control group, the results appear to be almost as there are many overlaps and neither of the two zigzag lines is "overriding". 


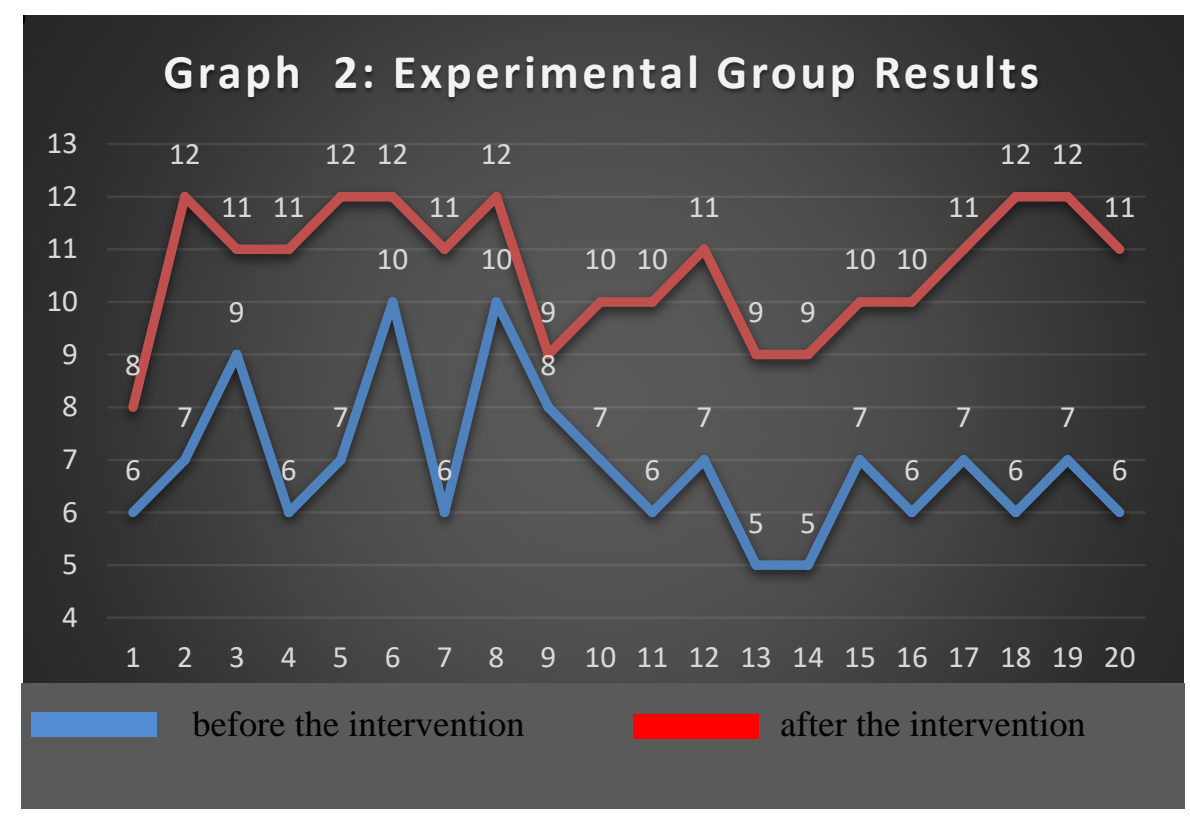

Figure 2. Experimental Group Results

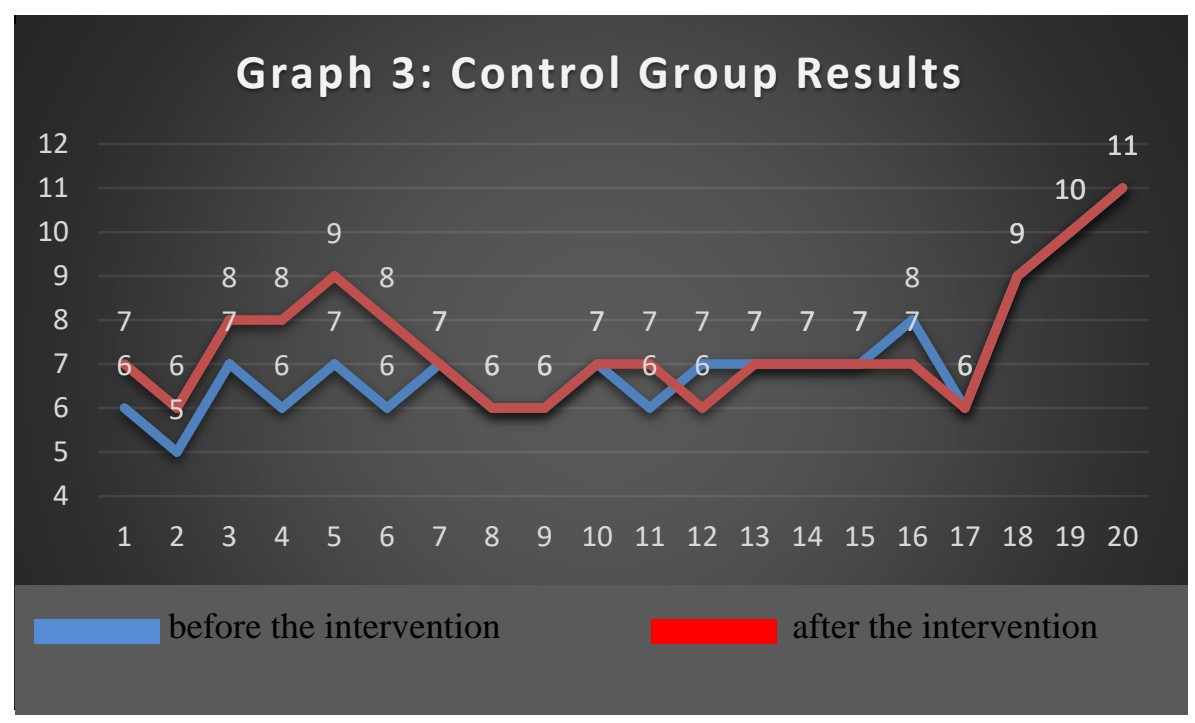

Figure 3. Experimental Group Results

All of the above, in order to acquire mathematical validity, should be considered more focused, through statistical tests. In addition to the seemingly large (experimental) or small (in control) group, it is important to analyse statistically whether or not there was a difference between these scores.

In order to move forward and decide which would be the most appropriate statistical tests for each case, we needed to perform regularity checks for both Score variables (before and after). The most well-known and credible tests of tenacity are those of Kolmogorov-Smirnov and Shapiro-Wilk. However, the first test is considered a bit obsolete, so we used a later version of it (Lilliefors Significance Correction). These tests have no assumption that each of the variables studied, follow a normal distribution, assuming a 95\% confidence interval, when the p- value of the control occured below 0.05 .

As we see in Table 3, both tests reject regularity in each case, indicating more appropriate non-parametric controls (if regularity would occur, two more regularity checks would be performed, and if parametric tests were also acceptable). 
Table 3. Checks for regularity for scoring variables

\begin{tabular}{|c|c|c|c|c|c|c|c|}
\hline & \multirow{2}{*}{ Group } & \multicolumn{3}{|c|}{ Kolmogorov-Smirnov a } & \multicolumn{3}{|c|}{ Shapiro-Wilk } \\
\hline & & Statistics & $\mathrm{df}$ & Sig. & Statistics & $\mathrm{df}$ & Sig. \\
\hline \multirow{2}{*}{ Experimental } & $\begin{array}{c}\text { Performance before } \\
\text { intervention }\end{array}$ & .272 & 20 & .000 & .852 & 20 & .006 \\
\hline & $\begin{array}{l}\text { Performance after } \\
\text { intervention }\end{array}$ & .212 & 20 & .019 & .885 & 20 & .022 \\
\hline \multirow{2}{*}{ Control } & $\begin{array}{c}\text { Performance before } \\
\text { intervention }\end{array}$ & .314 & 20 & .000 & .817 & 20 & .002 \\
\hline & $\begin{array}{l}\text { Performance after } \\
\text { intervention }\end{array}$ & .277 & 20 & .000 & .854 & 20 & .006 \\
\hline
\end{tabular}

Among the most reliable non-parametric controls, for trivalent variables involving dependent specimens (depending on how we control the same before-and-after performance), is Wilcoxon's control. The zero hypothesis of this test is that there are no differences between the two measurements and is rejected when the p- value value is below 0.05 , indicating that $95 \%$, there was indeed a significant variation.

In our case, we want to check whether the differences identified in the two metrics of the experimental group are indeed significant, while at the same time we expect no significant difference between the "before" and the "after" for the control group.

In Table 4, therefore, the results of this test are presented. As we can see, the descriptive and intuitive results so far are being verified as we see that in the experimental group, the differences found were statistically significant $(\mathrm{P}$-value $=$ $0.000<0.05)$, whereas in the control group, not ( $\mathrm{p}$-value $=0.057>0.05)$.

Table 4. Wilcoxon Test, to show differences in "before" and "after" scores in both groups

\begin{tabular}{clc}
\hline & Group & $\begin{array}{c}\text { Performance before intervention - } \\
\text { Performance after intervention }\end{array}$ \\
\hline Experimental & Asymp. Sig. (2-tailed) & .000 \\
\hline Control & $\begin{array}{l}\text { Asymp. Sig. (2-tailed) } \\
\text { a. Wilcoxon Signed Ranks Test }\end{array}$ & .057 \\
& &
\end{tabular}

Finally, a comparison of gender outcomes was made for both groups. The comparison was made by the non-parametric Mann-Whitney test (Table 5), which is the analog of Wilcoxon when our samples are not associated (here, the subgroups are the boys and girls while before they were the same individuals in the previous and later).

Table 5. Mann-Whitney Test to show differences in gender scores

\begin{tabular}{|c|c|c|c|}
\hline Group & & $\begin{array}{l}\text { performance before } \\
\text { intervention }\end{array}$ & $\begin{array}{l}\text { Performance after } \\
\text { intervention }\end{array}$ \\
\hline Experimental & Asymp. Sig. & .545 & .811 \\
\hline Control & Asymp. Sig. & .072 & .906 \\
\hline \multicolumn{4}{|l|}{ a. Kruskal Wallis Test } \\
\hline b. Grouping Variable: Gender & & & \\
\hline
\end{tabular}

As we can see from the above table, the odds are not significantly different between the two sexes in any

of the 4 cases that were created (Experimental "Before" and "After", "Before" and "After"). Overall, the statistical processing and analysis of the data, as confirmed by the measurements in the above tables, resulted in the following results: 
Table 6. Statistical processing and analysis of the 4 levels

\begin{tabular}{|c|c|}
\hline \multirow{3}{*}{$\begin{array}{l}\text { Level } 1 \text { (control group - first } \\
\text { count): }\end{array}$} & $4(20 \%)$ on average \\
\hline & $15(75 \%)$ below the average \\
\hline & $1(10 \%)$ poor \\
\hline \multirow{2}{*}{$\begin{array}{l}\text { Level } 2 \text { (control group - } \\
\text { second measurement): }\end{array}$} & $7(35 \%)$ on average \\
\hline & $13(65 \%)$ below the average \\
\hline \multirow{3}{*}{$\begin{array}{l}\text { Level } 3 \text { (experimental group - } \\
\text { first measurement): }\end{array}$} & $4(20 \%)$ on average \\
\hline & $14(70 \%)$ below the average \\
\hline & $2(10 \%)$ poor level \\
\hline \multirow{2}{*}{$\begin{array}{l}\text { Level } 4 \text { (experimental group - } \\
\text { second measurement): }\end{array}$} & $4(20 \%)$ above average \\
\hline & $16(80 \%)$ on average \\
\hline
\end{tabular}

\section{Discussion}

The intervention program applied to children's centers has had positive results. In the experimental group, where the program was implemented, there was a significant improvement in basic motor skills according to the statistical results. Instead, the control group in which no interventions were performed did not show the same positive results as regards the performance of children in basic mobility skills. Children in the control group had little improvement in the second assessment, apparently due to the age maturity and elementary motor activities that pedagogues applied in their daily schedule.

Instead, the children of the experimental team improved their performance in running, horizontal jump, static jump, galloping, hopping and leaping.

It is worth noting that the results of this research are consistent with previous research, where the intervention with kinetic, rhythmic, psychomotoric programs was investigated and the groups showed a significant improvement in mobility skills (Lykesas, et al., 2014; Piek et al., 2013; Hardy et al., 2009; Valentini \& Rudisill, 2004; Campas et al., 2012; Livonesa, et all., 2011). Appropriate intervention programs improve the kinetic skills of young children and their application is deemed necessary (Madic, et all., 2018; Becker, 2013; Yilmaz \& Sicim-Sevim, 2018; Zachopoulou, et all, 2004; Shoval, et all., 2015; Venetsanou, Kambas, 2017; Wang, 2004; Goodway, et all., 2003).

I. As far as the first question of the study is concerned on the effectiveness of the program in terms of motorized motor skills of children, the results are also encouraging. After the examination of the children and the statistical analysis of the kinetic tests, the children of the experimental group experienced a significant improvement in motor skills, especially on movements. The difference is evident and the results are statistically significant.

From very beginning, the child was required to develop motor skills in a variety of activities, particularly in younger ages and in school, where their successful performance amounts to social acceptance and popularity. Therefore, self-esteem and social skills seem to be enhanced.

Moreover, motor dexterity can cause negative criticism and disapproval. Many children are the victims of school bullying because of their motor skills, and consequently their inability to successfully participate in sports activities.

According to Gallahue (2002), the high degree of performance in a person's motor skills does not arise as a result of any inherent talent or inheritance but as a combination of important factors such as practice, encouragement and teaching, a position confirmed by results of the case study we present.

II. Regarding the second question concerning the control group, children did not improve, in comparison to the experimental group where the children scored higher than the average. In gross motion (movements), the difference was evident and the results were statistically significant.

Performance evaluation is based on the manual accompanying the two kinetic tests (rough and fine movements handlings). In this way, the degree to which each child is assessed and then according to the score is evaluated.

According to the results of the Urlich Test, children aged 4 to 5 who applied this program showed "above the average" performance. Children of the group that did not apply the program remained at "average" and "below average".

It seems that these children were unable to reach a moderate level, as opposed to the experimental group, which has exceeded the average. This confirms the effectiveness of appropriate kinetic programs, with animation intervention. After examination by means of the two kinetic tests and the statistical analysis of the results, children develop kinetic skills after 
a special program intervention and animation intervention (Zimmer et all., 1987; Tsapakidou, 2014; Derri, et all., 2014; Yilmaz \& Sicim-Sevim, 2018; Madic et all., 2018).

III. Concerning the third question of the study, regarding the diversification of boys and girls, the results showed that there is no significant difference. Many studies agree with the findings of the present study on gender, especially in preschool age, and differ significantly for older adults (Kampa et al., 2003, 2001; Roth \& Winter, 1994; Zimmer \& Volkamer, 1987; Hirtz, 1985; Becker, 2013, 2015; Gallahue et all., 2011 ; Malina et al., 2004 ; Zaragas, 2016 ; Madic, et all., 2018).

IV. As far as the fourth question of the study is concerned, regarding the Process and Didactics which the teacher intervention followed, there has been a variety of activities with the element of exploration and guided discovery, which has encouraged children and increased interest in creative action. It directed children to discover their body, space and collaboration with inanimate and living elements. Through this process, children expressed themselves creatively, got familiar with the particularities of different cultures and improved their skills and abilities. Creative dance is an approach and should be treated in that way within school curriculum. It will allow personalities to grow, giving holistic knowledge and will promote health.

Through movement, children "discovered the world", approached previously unknown concepts, communicated, collaborated, exchanged their feelings and thoughts (Zachopoulou et all., 2007; Derri, et all., 2014; Piaget, 1962).

Evaluating the specific educational intervention, we consider that in terms of program effectiveness the results were both quantitative and qualitative in line with children's progress in motor skills and the acceptance and enjoyment of the programs (Zimmer, 1991; Tsapakidou et all., 2001; Venetsanou \& Kambas, 2017; Iivonena et all., 2011; Tsapakidou, 2014; Yilmaz \& Sicim-Sevim, 2018).

In conclusion, interventional kinetic programs seem to target multiple areas of both motor, cognitive, emotional, and general health. This is because kinetic programs create an attractive atmosphere, increasing the attention of children (Pica, 2004; Yilmaz et all., 2018 ; Zarić et all., 2018 ; Klingberg et al., 2018). Pre-school age is considered as an appropriate period for the implementation of programs that aim at promoting motor skills. It is the age where the foundations of children's fundamental skills are built, which will later develop into sports skills (Gallahue, 2002). Therefore, it is sensible that the guidelines in pre-primary education emphasize that the development and promotion of motor skills should be an integral part of the educational programs (Vidin, et all, 2014). Although children can acquire elementary motor skills through maturation processes, mature forms of skills can only be achieved in a developmental-friendly environment that provides encouragement, opportunities for specific practice of skills, as well as a challenging natural environment, which inspires and aims at integrating skills into different contexts. A significant role is played by the teacher who encourages creativity, giving opportunities and creating space for improvisational activities.

\section{References}

Becker, K. M. (2013). Dancing through the school day: How dance catapults learning in elementary education. Journal of Physical Education, Recreation \& Dance, 84(3), 6-8. https://doi.org/10.1080/07303084.2013.763665

Berris, R., \& Miller, E. (2011). How design of the physical environment impacts early learning: educators and parents perspectives. Australasian Journal of Early Childhood, 36(4). https://doi.org/10.1177/183693911103600414

Čillík, I., \& Willwéber, T. (2018). Influence of an exercise programme on level of coordination in children aged 6 to 7. Journal of Human Sport and Exercise, 13(2). https://doi.org/10.14198/jhse.2018.132.14

Clark, J. E., Clements, R. L., Guddemi, M., Morgan, D. W., Pica, R., Pivarnik, J. M., ... \& Virgilio, S. J. (2002). Active start: A statement of physical activity guidelines for children birth to five years. AAHPERD Publications, PO Box 385, Oxon Hill, MD 20750-0385 Stock no. 304-10254.

Derri, V., Aggelousis, N., \& Petraki, C. (2004). Health-related fitness and nutritional practices: can it be enhanced in upper elementary school students? The Physical Educator, 61, 35-41. https://doi.org/10.1080/1740898010060103

Derri, V., Tsapakidou, A., Zachopoulou, E., \& Kioumourtzoglou, E. (2001). Effect of a Music and Movement Programme on Development of Locomotor Skills by Children 4 to 6 Years of Age. European Journal of Physical Education, 6, 16-25. http://dx.doi.org/10.1080/1740898010060103

Dyment, J., \& Coleman, B. (2012). The intersection of physical activity opportunities and the role of early childhood educators during outdoor play: Perceptions and reality. Australasian Journal of Early Childhood, 37(1), 90. https://doi.org/10.1177/183693911203700111

Gallahue, D. L. (2002). Developmental physical education for today's children. Thessaloniki: University studiopress.

Gardner, A. L. (1993). Order didelphimorphia. Mammal species of the world, 15-23.

Goodway, J. D., Crowe, H., \& Ward, P. (2003). Effects of motor skill instruction on fundamental motor skill 
development. Adapted Physical Activity Quarterly, 20(3), 298-314. https://doi.org/10.1123/apaq.20.3.298

Guilford, J. P. (1950). Creativity. American Psychologist, 5, 444-454. https://doi.org/10.1037/h0063487

Hardy, L. L., King, L., Farrell, L., Macniven, R., \& Howlett, S. (2010). Fundamental movement skills among Australian preschool children. Journal of Science and Medicine in Sport, 13(5), 503-508. https://doi.org/10.1016/j.jsams.2009.05.010

Hinkley, T., Crawford, D., Salmon, J., Okely, A. D., \& Hesketh, K. (2008). Preschool children and physical activity: a review of correlates. American journal of preventive medicine, 34(5), 435-441. https://doi.org/10.1016/j.amepre.2008.02.001

Hirtz, J. (1985). The gastrointestinal absorption of drugs in man: a review of current concepts and methods of investigation. British journal of clinical pharmacology, $19(\mathrm{~S} 2)$, $77 \mathrm{~S}-83 \mathrm{~S}$. https://doi.org/10.1111/j.1365-2125.1985.tb02746.x

Iivonen, S., Sääkslahti, A., \& Nissinen, K. (2011). The development of fundamental motor skills of four-to five-year-old preschool children and the effects of a preschool physical education curriculum. Early Child Development and Care, 181(3), 335-343. https://doi.org/10.1080/03004430903387461

Kambas, A., Venetsanou, F., Giannakidou, D., Fatouros, I. G., Avloniti, A., Chatzinikolaou, A., \& Zimmer, R. (2012). The Motor-Proficiency-Test for children between 4 and 6 years of age (MOT 4-6): An investigation of its suitability in Greece. Research in Developmental Disabilities, 33(5), 1626-1632. https://doi.org/10.1016/j.ridd.2012.04.002

Kambas, K., Mitroulis, I., Apostolidou, E., Girod, A., Chrysanthopoulou, A., Pneumatikos, I., ... \& Ritis, K. (2012). Autophagy mediates the delivery of thrombogenic tissue factor to neutrophil extracellular traps in human sepsis. PloS one, 7(9), e45427. https://doi.org/10.1371/journal.pone.0045427

Kampas, A., Gourgoulis, B., Fatouros, I., Aggelousis, N., Probiadaki, E., \& Taksildaris, K. (2005). Effect psychomotor therapy program on motor performance in preschool children. Physical Education \& Sports, 56, 49-59.

Klingberg, B., Schranz, N., Barnett, L. M., Booth, V., \& Ferrar, K. (2018). The feasibility of fundamental movement skill assessments for pre-school aged children. Journal of sports sciences, 1-9.

Köckenberger, W., De Panfilis, C., Santoro, D., Dahiya, P., \& Rawsthorne, S. (2004). High resolution NMR microscopy of plants and fungi. Journal of Microscopy, 214(2), 182-189. https://doi.org/10.1111/j.0022-2720.2004.01351.X

Laban, R. (1975). Modern educational dance. Princeton Book Co Pub.

Livonesa, S., Saakslahtia, A., \& Nissinen, K., (2011). The development of fundamental motor skills of four - to five year ald preschool children and the effects of a preschool physical education curriculum, Early child Development and Care, 181(3), 335-343. https://doi.org/10.1080/03004430903387461

Lykesas, G., \& Papadopoulou, S. (2007). A proposal for the teaching approach of Greek traditional dances in school practice through music and movement education, Music in Elementary School, 1, 62-69.

Lykesas, G., \& Koutsouba, M. (2008). The teaching of Greek traditional dance in school education with the adoption of creative methods of teaching. Journal of Health and Sport Performance, 3, 37-49.

Lykesas, G., Koutsouba, M., \& Tyrovola, V. (2009). Creativity as an approach and teaching method of traditional Greek dance in secondary schools. Studies in Physical Culture \& Tourism, 16(2).

Lykesas, G., Thomaidou, E., Tsompanaki, T., Papadopoulou, D. S., \& Tsapakidou, A. (2003). Development of motor fluency - flexibility and originality through motor creativity in kindergarten, Inquiries in Sport \& Physical Education, 1(3), 211-220.

Madić, D., Cvetković, M., Popović, B., Marinković, D., Radanović, D., \& Trajković, N. (2018). Effects of developmental gymnastics on motor fitness in preschool girls. Facta Universitatis, Series: Physical Education and Sport, 16(1), 011-018. https://doi.org/10.22190/FUPES180122002M

Malina, R. M., Eisenmann, J. C., Cumming, S. P., Ribeiro, B., \& Aroso, J. (2004). Maturity-associated variation in the growth and functional capacities of youth football (soccer) players 13-15 years. European journal of applied physiology, 91(5-6), 555-562. https://doi.org/10.1007/s00421-003-0995-z

McFee, G. (2004). Sport, rules and values: Philosophical investigations into the nature of sport. Routledge. https://doi.org/10.4324/9780203299876

McFee, J. L. (1985) Society, art, and education. in Spenser, P. (ed). (1985) Society and the dance. Cambridge: Cambridge University Press. 
Montessori, M., \& Carter, B. (1936). The secret of childhood. Calcutta: Orient Longmans.

Mülazımoğlu-Ballı, Ö. (2016). Motor proficiency and body mass index of preschool children: In relation to socioeconomic status. Journal of Education and Training Studies, 4(4), $237-243$. https://doi.org/10.11114/jets.v4i4.1302

Pavlidou, E., Chatzigeorgiou, S., \& Galganopoulou, C. (2018). Kinetic development through a interdisciplinary programme of physical education and child literature in kindergarten. The Dialog magazine! Theory and Practice in education science, 4, 39-61.

Piaget, J. (1962). Comments on Vygotsky's Critical Remarks Concerning the Language and Thought of the Child and Judgment and Reasoning in the Child. Translated From Reasoning in the Child.\# Translated From the French by Anne Parsons.

Pica, R. (2004). Experiences in movement: Birth to age eight. Cengage Learning.

Piek, T. (Ed.) (2013). Venoms of the Hymenoptera: biochemical, pharmacological and behavioural aspects. Elsevier.

Roth, K., \& Winter, R. (1994). Entwicklung koordinativer fähigkeiten. Motorische Entwicklung, 191-217.

Shoval, E., Zaretzky, E., Sharir, T., \& Shulruf, B. (2015). The impact of free-choice motor activities on children's balance control. Australasian journal of early childhood, 40(4), 66. https://doi.org/10.1177/183693911504000409

Smith-Autard, J. M. (2002). The art of dance in education. A\&C Black.

Spanaki, I. E., Venetsanou, F., Evaggelinou, C., \& Skordilis, E. K. (2014). Graphomotor skills of Greek kindergarten and elementary school children: Effect of a fine motor intervention program. Comprehensive Psychology, 3, 01-09. https://doi.org/10.2466/01.09.IT.3.2

Torrance, E. P. (1965). Rewarding Creative Behavior; Experiments in Classroom Creativity.

Tsapakidou, A., \& Zachopoulou, E. (2001). Interdisciplinary teaching: Cultivating oral speech through movement and rhythm. Physical activity and quality of life, 2, 28-34.

Tsapakidou, A., Stefanidou, S., \& Tsompanaki, E. (2014). Locomotor development of children aged 3.5 to 5 years in nursery schools in Greece. Review of European Studies, 6(2), 1. https://doi.org/10.5539/res.v6n2p1

Tsompanaki, E. (2009). A comparative study of dance education and training in tertiary education in England and Greece (Doctoral dissertation, The University of Birmingham).

Tucker, P. (2008). The physical activity levels of preschool-aged children: A systematic review. Early Childhood Research Quarterly, 23(4), 547-558. https://doi.org/10.1016/j.ecresq.2008.08.005

Valentini, N. C., \& Rudisill, M. E. (2004). Motivational climate, motor-skill development, and perceived competence: Two studies of developmentally delayed kindergarten children. Journal of teaching in physical education, 23(3), 216-234. https://doi.org/10.1123/jtpe.23.3.216

Venetsanou, F., \& Kambas, A. (2004). How can a traditional Greek dances programme affect the motor proficiency of pre-school children?. Research in Dance Education, 5(2), 127-138. https://doi.org/10.1080/14617890500064019

Venetsanou, F., \& Kambas, A. (2010). Environmental factors affecting preschoolers' motor development. Early childhood education journal, 37(4), 319-327. https://doi.org/10.1007/s10643-009-0350-z

Venetsanou, F., \& Kambas, A. (2017). Physical activity promotion in Greek preschools: The gap between theory and practice. Early Childhood Education Journal, 45, 437-444. https://doi.org/10.1007/s10643-016-0788-8

Venetsanou, F., Kambas, A., Aggeloussis, N., Fatouros, I., \& Taxildaris, K. (2009). Motor assessment of preschool aged children: A preliminary investigation of the validity of the Bruininks-Oseretsky test of motor proficiency-Short form. Human Movement Science, 28(4), 543-550. https://doi.org/10.1016/j.humov.2009.03.002

Vidoni, C., Lorenz, D. J., \& de Paleville, D. T. (2014). Incorporating a movement skill programme into a preschool daily schedule. Early Child Development and Care, 184(8), 1211-1222. https://doi.org/10.1080/03004430.2013.856895

Wang, J. H. T. (2004). A study on gross motor skills of preschool children. Journal of research in childhood education, 19(1), 32-43. https://doi.org/10.1080/02568540409595052

Wang, J., Wolf, R. M., Caldwell, J. W., Kollman, P. A., \& Case, D. A. (2004). Development and testing of a general amber force field. Journal of computational chemistry, 25(9), 1157-1174. https://doi.org/10.1002/jcc.20035

Xanthakou, G. (1998). Creativity in school. Athens:Greek Letters. 
Yılmaz, S., \& Sicim-Sevim, B. (2018). The examination of the differences in the motor proficiency skills of children practising gymnastics vs. non-sportive children. Early Child Development and Care, 1-8. https://doi.org/10.1080/03004430.2018.1559159

Zachopoulou, E., \& Makri, A. (2005). A developmental perspective of divergent movement ability in early young children. Early Child Development and Care, 175, 85-95. https://doi.org/10.1080/0300443042000230401

Zachopoulou, E., Trevlas, E., Konstadinidou, E., \& Archimedes Project Research Group. (2006). The design and implementation of a physical education program to promote children's creativity in the early years. International Journal of Early Years Education, 14(3), 279-294. https://doi.org/10.1080/09669760600880043

Zachopoulou, E., Tsangaridou, N., Pickup, I., Liukkonen, J., \& Grammatikopoulos, V. (2007). Early Steps, promoting healthy lifestyle and social interaction through physical education activities during preschool years. Thessaloniki: Christodoulidi publications.

Zachopoulou, E., Tsapakidou, A., \& Derri, V. (2004). The effects of a developmentally appropriate music and movement program on motor performance. Early Childhood Research Quarterly, 19, 631-642. https://doi.org/10.1016/j.ecresq.2004.10.005

Zarić, D., Gojković, Z., Sporiš, G., \& Madić, D. (2018). Healthrelated fitness in preschool children: Difference between organized and unorganized physical activity. Exercise and Quality of Life, 10(1), 29-34. https://doi.org/10.31382/eqol.180603

Zieff, S. G., Lumpkin, A., Guedes, C., \& Eguaoje, T. (2009). NASPE sets the standard: 35 years of national leadership in sport and physical education. Journal of Physical Education, Recreation \& Dance, 80(8), 46-49. https://doi.org/10.1080/07303084.2009.10598378

Zimmer, R., \& Volkamer, M. (1987). Motoriktest für vier-bis sechsjährige Kinder: Mot 4-6; Manual. Beltz-Test.

\section{Copyrights}

Copyright for this article is retained by the author(s), with first publication rights granted to the journal.

This is an open-access article distributed under the terms and conditions of the Creative Commons Attribution license (http://creativecommons.org/licenses/by/4.0/). 